\title{
Periodontal bioengineering with mesenchymal stem cells
}

\author{
Nerea Sanchez, Mariano Sanz \\ Etiology and Therapy of Periodontal and Peri-implant Diseases Research Group, Faculty of Odontology, Complutense University \\ of Madrid, University Complutense, Madrid 28040, Spain. \\ Correspondence to: Dr. Nerea Sánchez, Etiology and Therapy of Periodontal and Peri-implant Diseases Research Group, Faculty \\ of Odontology, University Complutense of Madrid, Plaza Ramón y Cajal s/n (Ciudad Universitaria), Madrid 28040, Spain. \\ E-mail: nereasanchez@ucm.es
}

How to cite this article: Sanchez N, Sanz M. Periodontal bioengineering with mesenchymal stem cells. Plast Aesthet Res 2021;8:55. https://dx.doi.org/10.20517/2347-9264.2021.26

Received: 23 Mar 2021 First Decision: 28 Jun 2021 Revised: 8 Jul 2021 Accepted: 28 Aug 2021 Published: 15 Oct 2021

Academic Editors: Hiroshi Mizuno, Paolo Boffano, Mario Aimetti Copy Editor: Xi-Jun Chen Production Editor: Xi-Jun Chen

\begin{abstract}
Current periodontal regenerative therapies aim at restitution ad integrum of the periodontal attachment apparatus, which involves periodontal ligament, root cementum, and alveolar bone. Guided tissue regeneration, bioactive agents and bone replacement grafts have been utilized in an attempt to fully restore the lost periodontal tissues. But their predictability has been limited and dependent on patient- and defect-related factors. Consequently, the treatment of most periodontal defects still lacks satisfactory and predictable outcomes. Cell therapies, based on the use of mesenchymal stem cells (MSCs), represent a promising therapeutic strategy in light of recently available published preclinical investigations and clinical studies. The application of MSCs in humans is being performed by two different strategies: (1) the ex vivo culture of undifferentiated MSCs from autologous or allogeneic sources, subjected to specific cell expansion and characterization/differentiation tests to obtain the required cell counts for transplantation; and (2) the use of autologous tissue grafts and micrografts, which apart from MSCs, contain other biologically active cell populations and their extracellular matrix. This review evaluates the current status of MSCs therapy applied for periodontal regeneration, describing not only their mechanism of action, but also their efficacy and safety according to the published evidence.
\end{abstract}

Keywords: Periodontal regeneration, mesenchymal stem cells, cell therapy, tissue engineering 


\section{INTRODUCTION}

Periodontitis is a chronic multifactorial inflammatory disease associated with dysbiotic plaque biofilms and characterized by progressive destruction of the tooth-supporting apparatus (periodontal ligament, cementum, and alveolar bone) induced by the alteration of the homeostasis between the subgingival microbiota and the host immune response ${ }^{[1]}$.

According to a systematic review with data from 37 countries, aimed at consolidating the epidemiologic records about the most destructive forms of periodontal disease, severe periodontitis was the sixth most prevalent medical condition in world, with a prevalence of $11.2 \%$. In addition, it shows a significant increase with age and a peak incidence at 38 years old ${ }^{[2]}$. Severe periodontitis is widely distributed throughout the world and remains a public health concern ${ }^{[3]}$. Besides, periodontitis is associated with several systemic diseases and conditions ${ }^{[4,5]}$ and, therefore, periodontal treatment would not only arrest periodontal inflammation and allow recovery of oral health, but it may also influence the course of these associated systemic diseases, or at least, in promoting a relevant improvement in biomarkers associated with them ${ }^{[6-9]}$. Therefore, the control of the disease may influence the long-term general health of periodontitis patients ${ }^{[3]}$.

Conventional therapeutic strategies for periodontitis have focused on the infection control of the disease and the arrest of chronic inflammation, but not on the restoration of the injured tooth supporting tissues ${ }^{[10]}$. However, many periodontal regenerative therapies have aimed to reconstruct these tissues ${ }^{[11]}$ by the formation of a new connective tissue attachment with well-oriented collagen fibres attached to the newformed root cementum ${ }^{[12]}$. Since the 1970s, multiple investigations have evaluated different agents and biomaterials that would promote cells from the periodontal ligament (PDL) cells, as the only cell population capable of repopulate the affected root surface, and thus regenerating the lost periodontal attachment ${ }^{[13]}$ These technologies were based on the application of barrier membranes, bone replacement grafts, biologically active agents, and combinations of them; although, not all these strategies have provided the same level of evidence with regards to the efficacy in creating a new connective tissue attachment ${ }^{[14]}$.

Recent systematic reviews of randomized controlled clinical trials have reported that strategies based on guided tissue regeneration (GTR) and the use of biologically active agents, in particular, enamel matrix derivatives (EMD), when used in the treatment of intrabony and furcation defects, provided an added clinical benefit of $1.43 \mathrm{~mm}(0.76-2.22 \mathrm{~mm})$ and $1.27 \mathrm{~mm}(0.79-1.74 \mathrm{~mm})$, respectively, in terms of clinical attachment level (CAL) gains when compared to an open flap debridement (OFD) alone ${ }^{[15,16]}$. Furthermore, the data shows that the addition of a bone replacement graft may improve in some defect configurations, the results obtained with the application of either GTR or EMD ${ }^{[1,16]}$. Conversely, the use of strategies with a minimally invasive surgical approach like the minimally invasive surgical technique (MIST) ${ }^{[17]}$, the modified MIST technique (M-MIST) ${ }^{[18,19]}$, or the single-flap approach ${ }^{[20]}$ have allowed maximizing CAL gain with a significant decrease of postoperative gingival recession ${ }^{[21]}$. In fact, the importance of microsurgical techniques with minimal flap raising and enhancement of primary wound closure and space maintenance could be greater than even the regeneration material employed. A randomized controlled clinical study, in which the M-MIST technique with and without regeneration material was analyzed in intrabony defects, no statistically significant differences were observed between both groups in terms of clinical and radiographic variables $^{[22]}$.

These reported benefits from current biomaterials and MISTs, however, are restricted to a specific defect anatomy, mainly deep intrabony defects and mandibular degree II furcations ${ }^{[17,18,23-26]}$. Most periodontal lesions, such as supracrestal defects, class III furcation involvement lesions, or wide 1-wall intrabony defects still do not have a predictable outcome with standard regenerative technologies ${ }^{[27,28]}$. For this reason, new 
tissue engineering strategies are being investigated in order to overcome the limitations of current regenerative technologies. The growing evidence in the field of cell therapy research is stimulating the use of live cells in periodontal regenerative medicine.

The aim of this review is to summarize the current status of cell therapy in periodontal regeneration, presenting the particular characteristics and potentials of stem cells and the most recent evidence regarding the application of different modalities of cell therapy for the regeneration of the tooth-supporting structures both in the preclinical and in the clinical field.

\section{WHAT IS CELL THERAPY?}

Over the last few decades, the concept of cell therapy, as a new technology for the regeneration of organs and tissues, has been introduced in regenerative therapies in multiple areas of medicine, such as cardiology and traumatology, among others ${ }^{[29-31]}$. Its objective is to restore the function of damaged tissues and organs by the use of diverse cell populations such as resident stem cells, multipotent adult cells, or embryonic stem cells ${ }^{[32]}$ which have proliferative and paracrine potential to promote the target tissue regeneration. These cell therapies usually include the use of three-dimensional matrices or "scaffolds" that guide cell growth and act as vehicles for the release of cells or bioactive molecules, thus supporting and enhancing their tissueinductive properties ${ }^{[33]}$.

"Stem cells" are the cells with the greatest proliferation capabilities since they are the most undifferentiated progenitors. They are characterized by self-renewal capacity, potential for indefinite proliferation, and capacity for differentiation into several cell lineages. Traditionally, two categories of stem cells have been described according to their origin and differentiation capacities: embryonic stem cells, which are pluripotent cells (able to differentiated to cells from the three embryonic lineages), and adult or postnatal stem cells, which are multipotent (capacity to differentiate into cells from their same embryonic layer) ${ }^{[34,35]}$.

Adult stem cells are located in most tissues and organs since they have important roles in tissue homeostasis and repair ${ }^{[35]}$. The use of these cells lacks the ethical and legal issues associated with embryonic stem cells and they have not been associated with tumor formation when transplanted in vivo. These facts have made this cell population as the preferred source of cells for current cell-based therapeutics ${ }^{[36,37]}$. Hematopoietic stem cells, have been employed during decades as therapeutic tool in bone marrow transplantations ${ }^{[38]}$. Mesenchymal stem cells or "mesenchymal stromal cells" (MSCs), were isolated in 1970s, from bone marrow aspirations, and were defined as a subpopulation of plastic-adherent fibroblast-like cells, that formed singlecell colonies under culture "colony-forming units fibroblasts" ${ }^{[39]}$. Several years later, these multipotent MSCs have become well characterized and their source is not only derived from bone marrow, but also from many other adult tissues, many from intraoral sources ${ }^{[39-43]}$. Among the extraoral tissues for collecting MSCs, the umbilical cord and the adipose tissue have been extensively used ${ }^{[44,45]}$. As for the intraoral sources, MSCs have been isolated from the periodontal ligament, the pulp from temporary and permanent teeth, the gingival connective tissue, the alveolar bone, the apical papilla, or the dental follicle $e^{[40-43,46-48]}$.

Since the first ex vivo preclinical studies with MSCs in the 1970s, many publications have investigated the

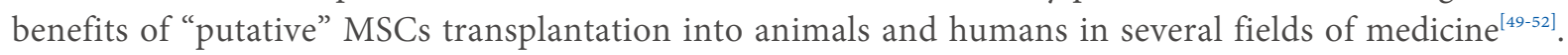
However, it was not until 2006, that the International Society for Cell Therapy established the minimal criteria for defining human multipotent MSCs for in vitro and preclinical investigations ${ }^{[33]}$. Thus, a general consensus worldwide about the characteristics of MSCs would allow comparing studies from many different research groups. According to that consensus, the requisites for being considered as MSCs were: (1) plasticadherence under standard culture conditions; (2) expression of specific mesenchymal phenotype markers 
by at least $95 \%$ of the MSCs population $\left(\mathrm{CD}^{\circ} 0^{+}, \mathrm{CD}^{+} 3^{+}, \mathrm{CD} 105^{+}\right)$, as measured by flow cytometry, and absence ( $\leq 2 \%$ expression) of CD $34, \mathrm{CD} 45, \mathrm{CD} 45, \mathrm{CD} 79 \alpha$ or $\mathrm{CD} 19, \mathrm{CD} 14$ or CD $11 \mathrm{~b}$ and HLA-DR class II; and (3) differentiation potential to osteoblasts, adipocytes, and chondrocytes under in vitro culture, demonstrated by cell staining ${ }^{[33]}$. In addition, as the ultimate goal of ex vivo MSCs expansion is human transplantation, the biosafety of the cells in the clinical setting must be ensured through the previous analysis of their genomic stability and confirmation of the lack of tumorigenic potential in small animal models ${ }^{[3]}$.

\section{MESENCHYMAL STEM CELLS IN REGENERATIVE MEDICINE}

MSCs-based strategies for regenerative therapies aim at stimulating the biological processes that lead to tissue regeneration through the privileged potential of undifferentiated progenitors ${ }^{[54]}$. Several pathways have been reported to describe the mechanisms by which MSCs exert their therapeutic effects. In vivo studies have demonstrated the capacity of MSCs to differentiate to cells from the damaged receptor tissue $^{[5,56]}$; in fact, histological evidence has showed that green fluorescence protein-labeled MSCs, were present within the new-formed tissues several weeks after their transplantation ${ }^{[57,58]}$. Other proposed mechanisms of the action of MSCs is based through their paracrine effects, that is, the release of soluble bioactive molecules and signals that influence the host's immune response and enhance the proliferation and differentiation of resident progenitor cells $^{[59]}$. This mechanism based on the promotion of the transplanted cells to assist in the tissue self-repair potential have also been tested using the "conditioned medium", that is, the medium where the cells have been cultured rather than transplanting the cells ${ }^{[00-62]}$. With this strategy, growth factors and other bioactive molecules that are released during cell expansion continue their activity when applied directly on the target tissues to regenerate by enhancing the cellular responses in the injured area in a similar way, but lacking the issues associated with the transplantation of living cells $s^{[0,61,63]}$.

It has long been believed that the tissue source where the cells are isolated would predispose the cell lineage of MSCs differentiation ${ }^{[64]}$. However, the evidence supporting that cells epigenetics is regulated by the tissue of origin is limited ${ }^{[65]}$. On the contrary, the property termed "cell plasticity" as the capacity of demonstrating potential to extend beyond the differentiated cell phenotypes of their resident tissue has been ascribed for $\operatorname{MSCs}^{[6]}$, which then may be considered as pluripotent cells $^{[67]}$. Several investigations have evaluated this potential studying and whether these transdifferentiated cells are really able to perform identical functions as the cells of the tissue towards which they have been differentiated ${ }^{[68]}$. The first protocols differentiating BMSCs into neurons for nervous system repair were described by Woodbury et al ${ }^{[69]}$. Subsequently, other investigations have applied epigenetic modifiers and neuronal induction signals being able to differentiate MSCs into neural-like cells ${ }^{[70]}$, although the functionality of these cells is not completely elucidated ${ }^{[7]}$. MSCs also exhibit important immunomodulatory properties, since they reduce the proliferation of $\mathrm{T}$ helper lymphocytes and suppress the proliferation of activated T lymphocytes, B cells, "natural killers" cells, dendritic cells, and neutrophils ${ }^{[72,73]}$, thus decreasing the production of proinflammatory cytokines. This property has allowed the use of cell therapies based on allogeneic transplantation of MSCs and also the development of cell therapies for autoimmune diseases ${ }^{[3,49,74,75]}$. Furthermore, MSCs have showed the capacity for homing into sites of injury after systemic infusion, a property orchestrated by certain chemotactic cytokines and integrins, that make MSCs interesting candidates for various medical disciplines ${ }^{[51]}$.

Another advantage of MSCs-based regenerative technologies is their minimally invasive isolation and lower morbidity in comparison with standard regenerative therapies. This is particularly applicable to their use in the oral and maxillofacial area where the treatment of alveolar ridge atrophies requires oral rehabilitation 
with dental implant ${ }^{[76]}$. In these clinical situations, the gold standard therapy is the autologous bone graft, which not only entails a great morbidity, but also has limitations with respect to the bone availability of the donor site ${ }^{[77,78]}$. Besides a lower morbidity, the use of MSCs would also improve the perspectives regarding graft availability, as the number of cell counts may be controlled during ex vivo expansion ${ }^{[37]}$.

\section{APPLICATIONS OF MESENCHYMAL STEM CELLS FOR PERIODONTAL REGENERATION}

During the last decades, several attempts based on the use of stem cells for periodontal bioengineering have been published. They have been based on the application of cells with proliferative and paracrine potentials, in combination with three-dimensional matrixes, with the objective of maintaining the blood clot stability and the space for the regeneration, and at the same time, stimulating the regenerative process, thus resulting in improved clinical outcomes when compared with standard treatments ${ }^{[79]}$. These attempts have evaluated different modalities of MSCs therapy ${ }^{[80-84]}$, some transplanting undifferentiated ex vivo expanded MSCs into the periodontal defect and others transplanting tissue micro-grafts with potentiality to contain MSCs, but without any ex vivo processing and cell culturing ${ }^{[85]}$.

\section{Use of undifferentiated ex vivo expanded MSCs for periodontal regeneration}

Isolation and ex vivo expansion of undifferentiated MSCs have been the most common strategy for cell therapy applied in periodontal regeneration and tested in preclinical studies ${ }^{[54,86,87]}$. Although there are multiple variations depending on the specific methods used by each research group, the standard isolation protocol for MSCs is based on the aspiration [bone marrow mesenchymal stem cells (BMSCs) or adipose tissue-derived MSCs (ADSCs)] ${ }^{[45,46]}$, surgical harvesting [gingiva-derived MSCs (GMSCs)] ${ }^{[37,40]}$, tooth extraction and root scraping [periodontal ligament (PDL-MSCs), dental follicle (DFCs), and apical papilla MSCs (SCAPs)] ${ }^{[4,48,88]}$, or collection of the pulp tissue [dental pulp stem cells from permanent (DPSCs) or exfoliated deciduous teeth (SHEDs) $]^{[42,43]}$. After isolation, solid samples are fragmented and digested in enzymatic solutions, usually type I collagenase $(3 \mathrm{mg} / \mathrm{mL})$ and dispase $(4 \mathrm{mg} / \mathrm{mL})$ for $30-60 \mathrm{~min}$ at $37^{\circ} \mathrm{C}^{[40,41,88]}$. Then, the suspension is centrifuged and filtered to obtain single cell suspensions that are seeded in tissue flaks with culture media, usually $\alpha$-modified Eagle's minimal essential medium ( $\alpha$-MEM) or Dulbecco's modified minimum essential medium/nutrient mixture F-12 (DMEM/F12), containing 10\% fetal calf serum, $2 \mathrm{mM} \mathrm{L}$-glutamine and $100 \mathrm{U} / \mathrm{mL}$ penicillin and $100 \mu \mathrm{g} / \mathrm{mL}$ streptomycin ${ }^{[89,90]}$. Cells are then incubated $\left(37^{\circ} \mathrm{C}, 5 \% \mathrm{CO}_{2}, 95 \%\right.$ humidity) until they reach $80 \%-90 \%$ confluence, and then they are trypsinized (trypsin-EDTA) and seeded again at a lower concentration until a proper cell count is attained $^{[91,92]}$.

Although most preclinical investigations have injected the MSCs suspensions in the target area or seeded them in tri-dimensional scaffolds, new approaches using cell sheets technology have been proposed ${ }^{[93-95]}$. This treatment consists of the ex vivo expanding of cell layers, which preserve, unlike standard culture techniques, their endogenous extracellular matrix, growth factors, and fibronectin molecules ${ }^{[81]}$. With this technology, no proteolytic enzymes, such as trypsin ${ }^{[96]}$, are used to prevent alterations of the extracellular microenvironment, and cells achieve confluency, within 80-150 $\mu \mathrm{m}$ cell layers (usually 4-5 layers) ${ }^{[97]}$, which can be directly transplanted into the defect without any scaffold ${ }^{[96]}$. Cell pellets or microtissues may also be tri-dimensionally manufactured from multilayer cell sheets; they are aggregates that increase the endogenous extracellular matrix secretion and exhibit improved mechanical properties and cell viability. These technologies aim to mimic the natural development of periodontal tissues by applying these PDLMSCs pellets to promote the complete reconstruction of cementum-periodontal ligament complexes ${ }^{[98]}$.

In addition to their local transplantation, MSCs have been applied systemically, based in their capacity to migrate to damaged areas and stimulate tissue repair. Yu et al. ${ }^{[99]}$ reported that BMSCs injected systemically 
moved to surgically created periodontal defects and contributed to the healing of the lesions.

New regenerative strategies in periodontal therapy, to be considered as appropriate and effective therapeutic tools, require reliable evidence derived from preclinical and clinical studies ${ }^{[100]}$. The first step involves the design of preclinical investigations in which periodontal defects that mimic the naturally occurring lesions in humans affected by periodontitis are experimentally created ${ }^{[4,86,101,102]}$. The selection of a particular preclinical model will depend on the type of defect (e.g., fenestration, furcation, or intrabony periodontal lesion), the study follow-up, and the main study endpoint. Large animal models, such as the non-human primate or the canine, despite their high cost, are preferred due to their biological and histological similarities to humans ${ }^{[102]}$. In these studies, the formation of a new periodontal ligament, bone, and cementum, as well as a new connective tissue attachment are histologically evaluated in a test group, in which the new material is assessed in comparison to a control group (the gold-standard therapy, a negative control device, etc. $)^{[100]}$. Experimental research is needed for successful translation of new regenerative periodontal strategies to the clinical setting. Afterwards, clinical studies, and especially, randomized controlled clinical trials are needed to determine, not only the safety and efficacy of a certain biomaterial, bioactive agent, or cell population for periodontal regeneration under ideal or controlled conditions in patients, but also the effectiveness of the device in normal clinical conditions ${ }^{[100,103]}$.

\section{Preclinical studies}

The first preclinical investigations evaluating the transplantation of ex vivo expanded MSCs into periodontal lesions were published in the $1990 \mathrm{~s}^{[104]}$. Thereafter, multiple experimental in vivo investigations have provided histological evidence of the formation of new cementum, connective tissue attachment, and bone formation when MSCs from bone marrow ${ }^{[105]}$, adipose tissue ${ }^{[106]}$, dental pulp from temporary and permanent teeth $^{[107]}$, periodontal ligament ${ }^{[89,91]}$, or gingival connective tissue ${ }^{[108]}$ were applied into experimentally created periodontal defects ${ }^{[5,86,87]}$.

Monsarrat et al. ${ }^{[54]}$ reported that most of this preclinical research published until 2013, was performed in the dog model (49\% of the studies), with MSCs with an autologous origin (63\% vs. 14\% allogeneic and 28\% xenogeneic) and harvested from intraoral sources (63\%). MSCs-based therapies have been tested in different periodontal defect models, such as buccal dehiscence, 2 and 3-wall intrabony, and type II and III furcation lesions, as well as critical size supracrestal periodontal defects ${ }^{[75,94,109-111]}$.

In the last years, the study of the tissue-inductive potential of allogeneic ${ }^{[75,94,111]}$ and xenogeneic MSCs ${ }^{[109,110]}$ has increased. These investigations have reported that the use of cells from other species or other individuals is safe, without eliciting relevant immunogenic reactions after their transplantations ${ }^{[109,111]}$.

Table 1 shows the most recent preclinical investigations in which the effect of a test group, consisting of the use of MSCs from different tissue sources, was histologically evaluated for periodontal regeneration ${ }^{[75,94,109-116]}$. The results from these studies vary depending on the control used. When the comparative control was open flap debridement alone, or with an adjunctive negative control [i.e., sodium chloride $(\mathrm{NaCl})$ solution injection], a clear and statistically significant superiority was reported in the test group applying a cell therapy ${ }^{[94,109,110,116]}$. Takewaki et al. ${ }^{[16]}$ histologically observed epithelium invasion with inflammatory cell infiltrate and lack of periodontal ligament and cementum formation after OFD, but on the contrary, a successful periodontal regeneration with mature bone, new cementum and well-oriented Sharpey's fibers when the OFD was combined with the application of autologous BMSCs clumps. Conversely, when the control group consisted of using the same three-dimensional scaffold without the cells, the results from different studies were heterogeneous ${ }^{[75,11,114]}$. The use of allogeneic and autologous 
Table 1. Preclinical studies (2016-2020) with large animal models, in which mesenchymal stem cells are compared with a control treatment with no cells, for periodontal regeneration

\begin{tabular}{|c|c|c|c|c|c|}
\hline $\begin{array}{l}\text { Author } \\
\text { (Country) }\end{array}$ & $\begin{array}{l}\text { Animal model/follow } \\
\text { up }\end{array}$ & Defect type & $\begin{array}{l}\text { Cell groups (MSCs/scaffold/GF- } \\
\text { gene) } \\
\text { Cells origin }\end{array}$ & Control groups & Cell transplantation method \\
\hline $\begin{array}{l}\text { Liu et al. }{ }^{[114]} \\
\text { (China) }\end{array}$ & $\begin{array}{l}\text { Beagle dog }(n=6) / 6 \\
\text { months }\end{array}$ & Buccal dehiscences ${ }^{*}$ & $\begin{array}{l}\text { BMSCs/DBBM-collagen } \\
\text { (AUT) }\end{array}$ & DBBM-collagen & Grafting after OFD \\
\hline $\begin{array}{l}\text { Hu et al. }{ }^{[109]} \\
\text { (China) }\end{array}$ & Minipigs $(n=12) / 3$ months & Three-wall intrabony defects ${ }^{*}$ & $\begin{array}{l}\text { (I) DPSCs injection } \\
\text { (II) VitC treated DPSCs sheets (XEN) }\end{array}$ & $\mathrm{NaCl}$ injection & $\begin{array}{l}\text { Grafting after OFD/subperiosteal } \\
\text { injection }\end{array}$ \\
\hline $\begin{array}{l}\text { Basan et al. }{ }^{[112]} \\
\text { (Germany) }\end{array}$ & Minipigs $(n=15) / 4$ months & Class II furcation defects ${ }^{*}$ & PDL-MSCs/CP + SMem (AUT) & $\begin{array}{l}\text { (a) CP + SMem } \\
\text { (b) CMem/HA-TCP + GF + } \\
\text { SMem } \\
\text { (c) CMem + SMem } \\
\text { (d) CM + SMem } \\
\text { (e) CM + GF + SMem } \\
\text { (f) blank + SMem }\end{array}$ & Grafting after OFD \\
\hline $\begin{array}{l}\text { Takewaki et al. }{ }^{[116]} \\
\text { (Japan) }\end{array}$ & $\begin{array}{l}\text { Beagle dogs }(n=7) / 3 \\
\text { months }\end{array}$ & Class III furcation defects ${ }^{\dagger}$ & $\begin{array}{l}\text { BMSCs sheets + osteogenic media } \\
\text { (AUT) }\end{array}$ & OFD & Grafting after OFD \\
\hline $\begin{array}{l}\text { Guo et al. }{ }^{[94]} \\
\text { (China) }\end{array}$ & $\begin{array}{l}\text { Beagle dogs }(n=5) / 3 \\
\text { months }\end{array}$ & 2-wall intrabony defects & $\begin{array}{l}\text { DFSCs sheets } \\
\text { PDL-MSCs sheets (ALLO) }\end{array}$ & - & Grafting after OFD \\
\hline $\begin{array}{l}\text { Nuñez et al. }{ }^{[111]} \\
\text { (Spain) }\end{array}$ & $\begin{array}{l}\text { Beagle dogs }(n= \\
\text { 9) } / 3 \text { months }\end{array}$ & Critical-size supra-alveolar defects $^{\varsigma}$ & PDL-MSCs/DBBM-collagen (ALLO) & DBBM-collagen & Grafting after OFD \\
\hline $\begin{array}{l}\text { Venkataiah et al. }{ }^{[75]} \\
\text { (Japan) }\end{array}$ & Minipigs $(n=4) / 1$ month & Furcation defect model & ADSCs/fibrin gel (AUT or ALLO) & Fibrin gel & Grafting after OFD \\
\hline $\begin{array}{l}\text { Rezaei et al. }{ }^{[115]} \\
\text { (Iran) }\end{array}$ & $\begin{array}{l}\text { Mongrel dogs }(n=5) / 2 \\
\text { months }\end{array}$ & Class II furcation defects ${ }^{\top}$ & $\begin{array}{l}\text { BMSCs/fibrin glue/PRP } \\
\text { BMSCs/fibrin glue (AUT) }\end{array}$ & $\begin{array}{l}\text { (a) PRP + fibrin glue } \\
\text { (b) Fibrin glue }\end{array}$ & Grafting after OFD \\
\hline $\begin{array}{l}\text { Li et al. }{ }^{[110]} \\
\text { (China) }\end{array}$ & Minipigs $(n=9) / 3$ months & $\begin{array}{l}\text { Bone defects in both sides of the mesial root of } \\
\text { lower 1st molar }\end{array}$ & $\begin{array}{l}\text { (I) SCAPs } \\
\text { (II) SCAPs } / \text { SFRP2 }\end{array}$ & Saline & Subperiosteal injection \\
\hline $\begin{array}{l}\text { Li et al. }{ }^{[113]} \\
\text { (China) }\end{array}$ & Minipigs $(n=6) / 3$ months & Class II furcation defects & DPSCs-IPs $/ \beta-T C P(A \cup T)$ & $\beta-\mathrm{TCP}$ & Grafting after OFD \\
\hline
\end{tabular}

*Surgically created defects and immediate regenerative intervention (no material for defect chronification). "Surgically created defects and alginate impression materials for 1 week. "Surgically created defects and silk

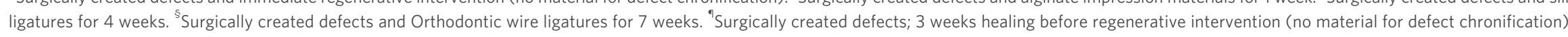
MSCs: Mesenchymal stem cells; GF: growth factor; BMSCs: bone marrow stem cells; DPSCs: dental pulp stem cells; PDL-MSCs: periodontal ligament-derived stem cells; ADSCs: adipose tissue-derived stem cells; SCAPs: apical papilla mesenchymal stem cells; DPSCs-IPs: stem cells from inflammatory dental pulp tissues; AUT: autologous; XEN: xenogeneic; ALLO: allogeneic; HA: hydroxyapatite; VitC: Vitamin C; CP: collagen powder; SMem: covered with semipermeable membrane; DBBM: demineralized bovine bone mineral; NaCl: sodium chloride; CMem: collagen membrane; CM: collagen matrix; OFD: open flap debridement; PRP: platelet-rich plasma; SFRPs: secreted frizzled-related proteins; CMem/HA-TCP: collagen membrane/hydroxilapatite-tricalcium phosphate; $\beta$-TCP: beta-tricalcium phosphate

ADSCs/fibrin gel constructs for the treatment of class II furcation models in minipigs provided new cementum, bone, and periodontal ligament, unlike the control group (fibrin gel), which showed lack of new tissues formation ${ }^{[75]}$. The micro-CT analysis revealed that the newly formed alveolar ratio in the allogeneic and autologous ADSCs groups was significantly greater (4.4 and 5.4 folds, respectively) than in the control group ${ }^{[75]}$. However, other publications did not 
report a significant added benefit with the application of MSCs ${ }^{[11,114]}$. Liu et al. ${ }^{[14]}$ treated buccal dehiscencetype defects in Beagle dogs with either autologous BMSCs seeded in collagen-hydroxyapatite scaffolds or the scaffolds alone. The results of the histometric analysis showed very similar dimensions with respect to the height of new-formed cementum (64\%-71\%) and bone (71\%-75\%) in both groups. Similarly, Nuñez et al. ${ }^{[111]}$ found no statistically significant differences for histometric values between a test group consisted of hydroxyapatite-collagen scaffolds with embedded allogeneic PDL-MSCs and a control group (scaffold alone) for the regenerative treatment of critical-size supraalveolar periodontal defects in Beagle dogs. In this study, the authors suggest that the limited effects of the cells could be attributable to the early soft tissue recession and exposure of the furcation fornix, what could have prevented from space maintenance and a satisfactory regenerative process ${ }^{[111]}[$ Table 1$]$.

In most studies the scaffold-cell construct has been applied directly into the periodontal defect after raising a full thickness flap and full debridement of the defect ${ }^{[92,112,116]}$. However, some authors have applied the cell therapy by a subperiosteal injection ${ }^{[110]}$. Hu et al. ${ }^{[109]}$ compared the regenerative efficacy of human DPSCs injections with DPSCs cell sheets placed after an OFD in a 3-wall intrabony defect model in minipigs. Although four months later, the histological results showed new alveolar bone and Sharpey's fibers attached to the new cementoid layers in both groups, the histometric analysis revealed a greater new-formed alveolar bone height in the grafted sites $(4.5 \pm 0.3 \mathrm{~mm})$ than in the areas treated by injected cells $(3.8 \pm 0.5 \mathrm{~mm} ; P>$ 0.05). This low superiority should not necessarily be attributed to the transplantation strategy, but to other reasons, such as the supplementation of the culture media with vitamin $\mathrm{C}$ in the grafted group or the inherent benefits of the cell sheet technique ${ }^{[109]}$. These methods in which the extracellular matrix is preserved, as cell sheets or pellets/aggregates techniques, have been increasingly tested in preclinical studies for periodontal regeneration ${ }^{[94,109,116]}$. Guo et al.$^{[9]}$ found that allogeneic DFSCs sheets showed better results in terms of new cementum $(5.16 \pm 0.23 \mathrm{~mm})$ and bone height $(4.67 \pm 0.35 \mathrm{~mm})$ than allogeneic PDL-MSCs sheets $(3.84 \pm 0.30 \mathrm{~mm}$ and $3.42 \pm 0.26 \mathrm{~mm}$, respectively), although these differences were not statistically significant. As scaffolds for carrying the cells, the most recent preclinical investigations have used fibrin gel $^{[75,115]}$, collagen materials (membranes, matrixes, and powder) ${ }^{[112]}$ and composite biomaterials made of hydroxyapatite and/or calcium phosphates mixed with collagen ${ }^{[11,112,114]}$ [Table 1].

\section{Clinical studies}

The safety and efficacy of the use of MSCs for periodontal regeneration demonstrated in preclinical studies, as well as their genomic stability shown in vitro, has prompted clinical investigations to assess their performance and efficacy in patients ${ }^{[37,54,86,87]}$. In the last decade, several clinical studies have studied the benefits of MSCs-based therapies in periodontal regeneration ${ }^{[5,7,7,81,82,84,85,117-119]}$. Their experimental design is shown in Table 2.

In terms of its safety, all clinical studies agree that MSCs-based therapies for periodontal regeneration are safe. No serious adverse events, other than the common complications of standard periodontal regenerative surgeries, such as medium-sized pain and swelling, sensitivity, and angular cheilosis, have been reported $^{[74,81,84,117,118,121]}$. Patients completely and spontaneously recovered in few weeks and no tooth lost was found during the follow up ${ }^{[117]}$.

Most of the published studies are case reports/series, with follow-ups ranging from 6 to 36 months, in which, the use of allogeneic or autologous MSCs for the treatment of intrabony, circumferential, and furcation defects, seems to significantly improve clinical and radiographic parameters ${ }^{[58,74,81,82,117-120]}$. 
Table 2. Design of clinical studies with MSCs for periodontal regeneration

\begin{tabular}{|c|c|c|c|c|c|}
\hline $\begin{array}{l}\text { Author } \\
\text { (Country) }\end{array}$ & $\begin{array}{l}\text { Design (follow } \\
\text { up) }\end{array}$ & n (final) & Test & Control & Type of defect \\
\hline $\begin{array}{l}\text { Yamada et al. }{ }^{[120]} \\
\text { (Japan) }\end{array}$ & CR (12 months) & 1 & BMSCs (AUT)/PRP & - & Intrabony defect \\
\hline $\begin{array}{l}\text { D'Aquino et al. }{ }^{[121]} \\
\text { (Italy) }\end{array}$ & $\begin{array}{l}\text { Split-mouth CCT } \\
\text { (12 months) }\end{array}$ & 7 & DPSCs (AUT)/collagen sponge & $\begin{array}{l}\text { Collagen } \\
\text { sponge }\end{array}$ & $\begin{array}{l}\text { Supraalveolar defects secondary to } \\
\text { third molar impaction }\end{array}$ \\
\hline $\begin{array}{l}\text { Yamada et al. } \\
\text { (Japan) }\end{array}$ & CS (6 months) & 17 & BMSCs (AUT)/PRP & - & Not reported \\
\hline $\begin{array}{l}\text { Dhote et al. }{ }^{[82]} \\
\text { (India) }\end{array}$ & $\begin{array}{l}\text { Parallel-group } \\
\text { RCT (12 months) }\end{array}$ & 20 & $\begin{array}{l}\text { Cord blood MSCs (ALLO)/ } \beta- \\
\text { TCP/PDGF-BB }\end{array}$ & OFD & Intrabony defects \\
\hline $\begin{array}{l}\text { Chen et al. }{ }^{[81]} \\
\text { (China) }\end{array}$ & $\begin{array}{l}\text { Parallel-group } \\
\text { RCT (12 months) }\end{array}$ & 30 & PDL-MSCs sheets (AUT)/DBBM & DBBM & Intrabony defects \\
\hline $\begin{array}{l}\text { Baba et al. }{ }^{[117]} \\
\text { (Japan) }\end{array}$ & CS (36 months) & 10 & BMSCs (AUT)/PRP/PLA & - & Intrabony defects (1, 2, and 3 walls) \\
\hline $\begin{array}{l}\text { Li et al }{ }^{[119]} \\
\text { (China) }\end{array}$ & CR (9 months) & 2 & DPSC-IPs $(A \cup T) / \beta-T C P$ & & Furcation defects \\
\hline $\begin{array}{l}\text { Iwata et al. }{ }^{[118]} \\
\text { (Japan) }\end{array}$ & CS (6 months) & 10 & PDL-MSCs sheets (AUT)/PGA/ $\beta$-TCP & - & $\begin{array}{l}\text { Intrabony defects (1, 2, 3-wall), } \\
\text { horizontal and circumferential } \\
\text { defects }\end{array}$ \\
\hline $\begin{array}{l}\text { Hernández- } \\
\text { Monjaraz et al. }{ }^{[74]} \\
\text { (Mexico) }\end{array}$ & CR (6 months) & 1 & $\begin{array}{l}\text { DPSC (ALLO)/collagen/PVP/non- } \\
\text { resorbable membrane }\end{array}$ & - & Circumferential defect \\
\hline $\begin{array}{l}\text { Sánchez et al. }{ }^{[84]} \\
\text { (Spain) }\end{array}$ & $\begin{array}{l}\text { Parallel-group } \\
\text { CCT (12 months) }\end{array}$ & 19 & PDL-MSCs (AUT)/DBBM-collagen & $\begin{array}{l}\text { DBBM- } \\
\text { collagen }\end{array}$ & Intrabony defects (1 and 2-wall) \\
\hline
\end{tabular}

CR: Case report; CCT: controlled clinical trial; CS: case series; RCT: randomized controlled clinical trial; BMSCs: bone marrow mesenchymal stem cells; DPSCs: dental pulp stem cells; MSCs: mesenchymal stem cells; PDL-MSCs: periodontal ligament-derived stem cells; AUT: autologous; ALLO: allogeneic; PRP: platelet-derived plasma; $\beta$-TCP: beta-tricalcium phosphate; PDGF-BB: platelet-derived growth factor-BB; DBBM: demineralized bovine bone mineral; PLA: poly-L-lactic acid resin; PGA: polyglycolid acid mesh; PVP: polyvinyl pyrrolidone sponge; OFD: open flap debridement.

Only three parallel-group controlled clinical trials, evaluating the effect of MSCs therapy on the functional regeneration of lost periodontal tissues, have been published to date $e^{[81,82,84]}$. They are all 12 -month controlled clinical trials, including 20-30 patients initially, suffering from periodontitis, with the presence of at least one tooth with a deep intrabony defect. Dhote et al.$^{[8]}$ reported significantly greater probing pocket depth reduction and CAL gain after treating the defects allocated to the test group with allogeneic cord blood MSCs cultured in a $\beta$-TCP scaffold with PDGF-BB, $(4.50 \pm 1.08 \mathrm{~mm}$ and $3.91 \pm 1.37 \mathrm{~mm}$, respectively), when compared with a control treatment, consisting of an OFD alone $(3.50 \pm 0.90 \mathrm{~mm}$ and $2.08 \pm 0.90 \mathrm{~mm}$, respectively; $P<0.05$ ). However, when in addition to the OFD, a scaffold was utilized as control treatment, the differences between the groups lost the statistical significance ${ }^{[81,84]}$. Chen et al. ${ }^{[8]}$ transplanted PDL-MSCs sheets together with demineralized bovine bone mineral (DBBM) in 21 intrabony periodontal defects, and the scaffold alone in 20 defects. Twelve months later, the results showed significant improvements in both groups, in terms of alveolar bone fill, the primary outcome variable in terms of efficacy, but differences between the cell and the control group could not be detected ${ }^{[81]}$. Similarly, Sánchez et al. ${ }^{[84]}$ did not find a significant added beneficial effect of transplanting autologous PDL-MSCs embedded in a DBBM/collagen scaffold when grafted in 1 and 2-wall intrabony defects, compared with the use of the same scaffold without the cells. However, in this study a clear trend favoring the cell group was reported in terms of mean probing pocket depth reduction and CAL gain. Unlike the two previous randomized controlled clinical trials (RCT), the latter study could not use a randomized allocation, as not all patients provided teeth with PDL samples exhibiting appropriate cell proliferation, thus the assignment of patients to the test group was based on the ability of cell growth from the periodontal ligament remnants from their extracted teeth ${ }^{[84]}$. 
In another controlled clinical trials, using a split-mouth design, DPSCs/collagen sponges constructs were transplanted into defects located in the distal aspect of lower second molars after the extraction of the impacted third molars ${ }^{[121]}$. The results derived from the evaluation of the seven patients that completed the 12 -month follow-up revealed that all the defects from the cell group attained $\geq 70 \%$ bone regeneration from their initial defect size whilst more than half of the control defects exhibited no regeneration or 30\% regeneration of the original defect dimension ${ }^{[121]}$.

Although the most common cell source in the MSCs-based clinical studies for periodontal regeneration has been the periodontal ligament ${ }^{[81,84,118]}$, other intraoral (dental pulp) and extraoral (bone marrow from the iliac crest) sites have been chosen for cell isolation with optimal cell counts after expansion ${ }^{[58,17,119,121]}$. In addition, most studies have employed cell populations from autologous tissues ${ }^{[58,81,84,177-121]}$; however, allogeneic sources are becoming an interesting alternative to autologous cells, due to their better costeffectiveness ${ }^{[74,82]}$.

In regards to the surgical technique, the method for cell transplantation into the defect in all the human studies was the OFD, with or without papilla preservation techniques, followed by the graft placement ${ }^{[18,82,84]}$ [Table 2].

\section{Whole tissue fractions without ex vivo culture}

This strategy is based on transplanting samples of autologous tissue, mainly from autologous periodontal ligament ${ }^{[80,122,123]}$ and dental pulp of permanent teeth ${ }^{[83,124-126]}$, with minimal manipulation and without ex vivo expansion ${ }^{[7]}$. Two different approaches of whole tissue fractions containing stem cells should be distinguished. In one, the tissue sample, immediately after its harvesting and isolation, is directly introduced into the periodontal defect without any manipulation ${ }^{[80,122,123]}$. On the other hand, the tissue samples once isolated, are mechanically disaggregated with special devices to attain a so-called "micrografts containing different cell fractions, with MSCs among them"[83,124-126].

One advantage of these strategies is the preservation of the extracellular matrix together with other cell fractions that are usually discarded when cultivating MSCs ex vivo. The hypothesis is that these cells and tissue fractions may have relevant roles in the maintenance of the niche/microenvironment where the stem cells exert their biological activity ${ }^{[123,125]}$. However, whole tissue fractions contain, not only MSCs, but also other progenitors and cell populations that although not having the differential cell inductive potential for regeneration, as monocytes and other hematopoietic cells, may release growth factors and signalling molecules, which in their physiologic ratios, may promote the regenerative process ${ }^{[127,128]}$. Another advantage of whole tissue fractions without ex vivo expansion is that all the procedures are performed in the dental chair at the same session, so that all regulatory issues when manipulating stem cells are avoided and consequently, their use is much more cost effective. In spite of the absence of preclinical evidence in animal models that confirms the regeneration of the periodontal tissues from a histological and histometric point of view $^{[129]}$, this cell therapy modality has been tested in various controlled clinical studies in which significantly better clinical outcomes have been shown by the "whole tissue fractions" group in comparison to the control group consisting of an OFD or the scaffold alone ${ }^{[80,83,123]}$ [Table 3].

In the first clinical report using non-manipulated tissue samples, periodontal ligament grafts, obtained by scraping the mid-third of the root of extracted third molars with a healthy periodontium, were immediate transplanted into class-II furcation lesions in mandibular molars ${ }^{[80]}$. When compared at six months with the control group using only coronally advanced flaps, the test group exhibited a greater CAL gain and probing pocket depth reduction $(P<0.05)$. A similar protocol, but, combining PDL scraped from the root surface 
Table 3. Design of clinical trials on periodontal regeneration with whole tissue fractions

\begin{tabular}{|c|c|c|c|c|c|c|}
\hline $\begin{array}{l}\text { Author } \\
\text { (Country) }\end{array}$ & $\begin{array}{l}\text { Design } \\
\text { (follow up) }\end{array}$ & $\begin{array}{l}n \\
\text { (final) }\end{array}$ & Test & Control & Grafts processing & $\begin{array}{l}\text { Periodontal } \\
\text { defect }\end{array}$ \\
\hline $\begin{array}{l}\text { Akbay et al. }{ }^{[80]} \\
\text { (Turkey) }\end{array}$ & $\begin{array}{l}\text { Split-mouth } \\
\text { RCT } \\
\text { (6 months) }\end{array}$ & 10 & PDL grafts (AUT) & OFD & None & $\begin{array}{l}\text { Degree II mandibular } \\
\text { furcation }\end{array}$ \\
\hline $\begin{array}{l}\text { Aimetti et al. }{ }^{[125]} \\
\text { (Italy) }\end{array}$ & $\begin{array}{l}\mathrm{CR}(12 \\
\text { months) }\end{array}$ & 1 & $\begin{array}{l}\text { DPSCs (AUT)/collagen } \\
\text { sponge }\end{array}$ & - & $\begin{array}{l}\text { Mechanical dissociation } \\
\text { (medimax system) }\end{array}$ & $\begin{array}{l}\text { 1, 2-wall intrabony } \\
\text { defect }\end{array}$ \\
\hline $\begin{array}{l}\text { Aimetti et al. }{ }^{[126]} \\
\text { (Italy) }\end{array}$ & $\begin{array}{l}\text { CR (12 } \\
\text { months) }\end{array}$ & 4 & $\begin{array}{l}\text { DPSCs (AUT)/collagen } \\
\text { sponge }\end{array}$ & - & $\begin{array}{l}\text { Mechanical dissociation } \\
\text { (medimachine system) }\end{array}$ & $\begin{array}{l}\text { 1- or } 2 \text {-wall intrabony } \\
\text { defect }\end{array}$ \\
\hline $\begin{array}{l}\mathrm{Kl} \text { et al. } \\
\text { (India) }^{[122]}\end{array}$ & $\begin{array}{l}\text { CR (12 } \\
\text { months) }\end{array}$ & 1 & $\begin{array}{l}\text { PDL grafts (AUT)/Gelatine } \\
\text { sponge }\end{array}$ & & None & Intrabony defect \\
\hline $\begin{array}{l}\text { Aimetti et al. }{ }^{[125]} \\
\text { (Italy) }\end{array}$ & $\begin{array}{l}\text { CS (12 } \\
\text { months) }\end{array}$ & 11 & $\begin{array}{l}\text { Micrografts rich in DPSC } \\
(\text { AUT)/collagen sponge }\end{array}$ & - & $\begin{array}{l}\text { Mechanical dissociation } \\
\text { (Rigenera system) }\end{array}$ & Intrabony defects \\
\hline $\begin{array}{l}\text { Ferrarotti et al. }{ }^{[83]} \\
\text { (Italy) }\end{array}$ & $\begin{array}{l}\text { Parallel-group } \\
\text { RCT } \\
\text { (12 months) }\end{array}$ & 29 & $\begin{array}{l}\text { Micrografts rich in DPSC } \\
(\text { AUT)/collagen sponge }\end{array}$ & $\begin{array}{l}\text { Collagen } \\
\text { sponge }\end{array}$ & $\begin{array}{l}\text { Mechanical dissociation } \\
\text { (Rigenera system) }\end{array}$ & Intrabony defects \\
\hline $\begin{array}{l}\text { Shalini et al. } \\
\text { (India) }\end{array}$ & $\begin{array}{l}\text { Parallel-group } \\
\text { RCT } \\
\text { (12 months) }\end{array}$ & 28 & PDL grafts (AUT) & OFD & None & Intrabony defects \\
\hline
\end{tabular}

RCT: Randomized controlled clinical trial; CR: case report; CS: case series; PDL: periodontal ligament; DPSCs: dental pulp stem cells; AUT: autologous; OFD: open flap debridement.

and the socket walls and mixed a gelatin sponge, the so-called "Autologous Stem Cell Assistance in Periodontal Regeneration (SAI-PRT)" was tested in a 12-month RCT, using as control group OFD in the treatment of intrabony defects ${ }^{[122,123]}$. This study also reported significant probing pocket depth reductions and CAL gains in the test group ${ }^{[123]}$.

In another protocol, the isolated tissues (in this case fresh pulpal tissue obtained immediately after tooth extraction), were mechanically disaggregated with a special device to obtain the so-called "micrografts", which were subsequently filtered and transplanted into the defects embedded in collagen sponges ${ }^{[124]}$. Clinical reports using this approach have shown beneficial clinical and radiographic effects when utilized for the treatment of non-contained intrabony defects ${ }^{[124-126]}$. Recently, a RCT compared the MIST to treat deep intrabony periodontal defects using either dental pulp micrografts placed in a collagen sponge biocomplex (test) or the same technique with the collagen sponge alone (control ${ }^{[83]}$. The results after 12 months showed that the application of the cell-based therapy significantly improved the clinical and radiographic parameters, suggesting that this strategy could represent a promising and easy method for periodontal regeneration ${ }^{[83]}$.

\section{CONCLUSION}

The scientific evidence from preclinical and clinical research has proven that the application of MSCs used in periodontal regenerative interventions is safe. These cell-based treatments can use either ex vivo expanded MSCs or minimally manipulated whole tissue fractions. The transplantation of ex vivo expanded MCSs into preclinical models of experimental periodontal defects have resulted in significant attainment of histological periodontal regeneration. However, the clinical evidence is still limited. When compared to OFD, this strategy has shown significant benefits in both clinical and radiographic outcomes. However, when the control group is the same biomaterial used as cell carrier without MSCs, controversial results have been published, although the number of RCTs is very limited. The implantation of whole tissue fractions (mainly dental pulp and periodontal ligament) has also reported significant clinical benefits when compared with a negative control group. However, the histological outcomes of this cell therapy strategy have not yet been reported. 
The present evidence of the efficacy and efficiency of these technologies based on cell therapies is too preliminary, with only a handful of clinical trials published. There is, therefore, a clear need of further clinical research, mainly in the form of RCT with adequate sample sizes, longer follow-ups, and robust designs. These designs should use patient-based analysis and the control group should be identical to the test group, but without cells or tissue extracts. Besides efficacy, other issues such as cost-effectiveness, patient morbidity, and patient-reported outcomes should be added.

\section{DECLARATIONS}

\section{Authors' contributions}

Wrote the manuscript and designed the tables summarizing the results: Sanchez N, Sanz M

\section{Availability of data and materials}

Not applicable.

\section{Financial support and sponsorship}

None.

\section{Conflicts of interest}

Both authors declared that there are no conflicts of interest.

\section{Ethical approval and consent to participate}

Not applicable.

\section{Consent for publication}

Not applicable.

\section{Copyright}

(c) The Author(s) 2021.

\section{REFERENCES}

1. Bartold PM, McCulloch CA, Narayanan AS, Pitaru S. Tissue engineering: a new paradigm for periodontal regeneration based on molecular and cell biology. Periodontol 2000 2000;24:253-69. DOI PubMed

2. Kassebaum NJ, Bernabé E, Dahiya M, Bhandari B, Murray CJ, Marcenes W. Global burden of severe periodontitis in 1990-2010: a systematic review and meta-regression. J Dent Res 2014;93:1045-53. DOI PubMed PMC

3. Genco RJ, Sanz M. Clinical and public health implications of periodontal and systemic diseases: an overview. Periodontol 2000 2020;83:7-13. DOI PubMed

4. Sanz M, Ceriello A, Buysschaert M, et al. Scientific evidence on the links between periodontal diseases and diabetes: consensus report and guidelines of the joint workshop on periodontal diseases and diabetes by the International Diabetes Federation and the European Federation of Periodontology. J Clin Periodontol 2018;45:138-49. DOI PubMed

5. Sanz M, Marco Del Castillo A, Jepsen S, et al. Periodontitis and cardiovascular diseases: consensus report. J Clin Periodontol 2020;47:268-88. DOI PubMed PMC

6. Chapple IL, Genco R; working group 2 of the joint EFP/AAP workshop. Diabetes and periodontal diseases: consensus report of the Joint EFP/AAP Workshop on Periodontitis and Systemic Diseases. J Periodontol 2013;84:S106-12. DOI PubMed

7. Linden GJ, Lyons A, Scannapieco FA. Periodontal systemic associations: review of the evidence. J Clin Periodontol 2013;40 Suppl 14:S8-19. DOI PubMed

8. Sanz M, Kornman K; working group 3 of the joint EFP/AAP workshop. Periodontitis and adverse pregnancy outcomes: consensus report of the Joint EFP/AAP Workshop on Periodontitis and Systemic Diseases. J Periodontol 2013;84:S164-9. DOI PubMed

9. Tonetti MS, Van Dyke TE; on behalf of working group 1 of the joint EFP/AAP workshop. Periodontitis and atherosclerotic cardiovascular disease: consensus report of the Joint EFP/AAPWorkshop on Periodontitis and Systemic Diseases. J Periodontol 2013;84:S24-9. DOI PubMed

10. Caton J, Nyman S, Zander H. Histometric evaluation of periodontal surgery. II. Connective tissue attachment levels after four regenerative procedures. J Clin Periodontol 1980;7:224-31. DOI PubMed

11. Nyman S, Gottlow J, Karring T, Lindhe J. The regenerative potential of the periodontal ligament. An experimental study in the monkey. J Clin Periodontol 1982;9:257-65. DOI PubMed 
12. Isidor F, Karring T, Nyman S, Lindhe J. New attachment-reattachment following reconstructive periodontal surgery. $J$ Clin Periodontol 1985;12:728-35. DOI PubMed

13. Sculean A, Nikolidakis D, Nikou G, Ivanovic A, Chapple IL, Stavropoulos A. Biomaterials for promoting periodontal regeneration in human intrabony defects: a systematic review. Periodontol 2000 2015;68:182-216. DOI PubMed

14. Cortellini P, Tonetti MS. Clinical concepts for regenerative therapy in intrabony defects. Periodontol 2000 2015;68:282-307. DOI PubMed

15. Jepsen S, Gennai S, Hirschfeld J, Kalemaj Z, Buti J, Graziani F. Regenerative surgical treatment of furcation defects: a systematic review and Bayesian network meta-analysis of randomized clinical trials. J Clin Periodontol 2020;47 Supp1 22:352-74. DOI PubMed

16. Nibali L, Koidou VP, Nieri M, Barbato L, Pagliaro U, Cairo F. Regenerative surgery versus access flap for the treatment of intrabony periodontal defects: a systematic review and meta-analysis. J Clin Periodontol 2020;47 Suppl 22:320-51. DOI PubMed

17. Cortellini P, Tonetti MS. Minimally invasive surgical technique and enamel matrix derivative in intra-bony defects. I: Clinical outcomes and morbidity. J Clin Periodontol 2007;34:1082-8. DOI PubMed

18. Cortellini P, Pini-Prato G, Nieri M, Tonetti MS. Minimally invasive surgical technique and enamel matrix derivative in intrabony defects: 2. Factors associated with healing outcomes. Int J Periodontics Restorative Dent 2009;29:257-65. PubMed

19. Cortellini P, Tonetti MS. Improved wound stability with a modified minimally invasive surgical technique in the regenerative treatment of isolated interdental intrabony defects. J Clin Periodontol 2009;36:157-63. DOI PubMed

20. Trombelli L, Farina R, Franceschetti G, Calura G. Single-flap approach with buccal access in periodontal reconstructive procedures. $J$ Periodontol 2009;80:353-60. DOI PubMed

21. Cortellini P. Minimally invasive surgical techniques in periodontal regeneration. J Evid Based Dent Pract 2012;12:89-100. DOI PubMed

22. Cortellini P, Tonetti MS. Clinical and radiographic outcomes of the modified minimally invasive surgical technique with and without regenerative materials: a randomized-controlled trial in intra-bony defects. J Clin Periodontol 2011;38:365-73. DOI PubMed

23. Cortellini P, Tonetti MS. Clinical performance of a regenerative strategy for intrabony defects: scientific evidence and clinical experience. J Periodontol 2005;76:341-50. DOI PubMed

24. Esposito M, Grusovin MG, Papanikolaou N, Coulthard P, Worthington HV. Enamel matrix derivative (Emdogain(R)) for periodontal tissue regeneration in intrabony defects. Cochrane Database Syst Rev 2009;2009:CD003875. DOI PubMed PMC

25. Needleman IG, Worthington HV, Giedrys-Leeper E, Tucker RJ. Guided tissue regeneration for periodontal infra-bony defects. Cochrane Database Syst Rev 2006;(2):CD001724. DOI PubMed

26. Sanz M, Giovannoli JL. Focus on furcation defects: guided tissue regeneration. Periodontol 2000 2000;22:169-89. DOI PubMed

27. Paolantonio M. Combined periodontal regenerative technique in human intrabony defects by collagen membranes and anorganic bovine bone. A controlled clinical study. J Periodontol 2002;73:158-66. DOI PubMed

28. Pontoriero R, Lindhe J. Guided tissue regeneration in the treatment of degree III furcation defects in maxillary molars. $J$ Clin Periodontol 1995;22:810-2. DOI PubMed

29. Fernandes TL, Cortez de SantAnna JP, Frisene I, et al. Systematic review of human dental pulp stem cells for cartilage regeneration. Tissue Eng Part B Rev 2020;26:1-12. DOI PubMed

30. Jeong H, Yim HW, Park HJ, et al. Mesenchymal stem cell therapy for ischemic heart disease: systematic review and meta-analysis. Int J Stem Cells 2018;11:1-12. DOI PubMed PMC

31. Nakamura K, Murry CE. Function follows form - a review of cardiac cell therapy. Circ J 2019;83:2399-412. DOI PubMed PMC

32. Sánchez A, Schimmang T, García-sancho J. Cell and tissue therapy in regenerative medicine. In: López-larrea C, López-vázquez A, Suárez-álvarez B, editors. Stem cell transplantation. New York: Springer US; 2012. p. 89-102. DOI

33. Han J, Menicanin D, Gronthos S, Bartold PM. Stem cells, tissue engineering and periodontal regeneration. Aust Dent J 2014;59 Suppl 1:117-30. DOI PubMed

34. García-Gómez I, Elvira G, Zapata AG, et al. Mesenchymal stem cells: biological properties and clinical applications. Expert Opin Biol Ther 2010;10:1453-68. DOI PubMed

35. Hynes K, Menicanin D, Gronthos S, Bartold PM. Clinical utility of stem cells for periodontal regeneration. Periodontol 2000 2012;59:203-27. DOI PubMed

36. King NM, Perrin J. Ethical issues in stem cell research and therapy. Stem Cell Res Ther 2014;5:85. DOI PubMed PMC

37. Santamaría S, Sanchez N, Sanz M, Garcia-Sanz JA. Comparison of periodontal ligament and gingiva-derived mesenchymal stem cells for regenerative therapies. Clin Oral Investig 2017;21:1095-102. DOI PubMed

38. Amouzegar A, Dey BR, Spitzer TR. Peripheral blood or bone marrow stem cells? Transfus Med Rev 2019;33:43-50. DOI PubMed

39. Friedenstein AJ, Chailakhjan RK, Lalykina KS. The development of fibroblast colonies in monolayer cultures of guinea-pig bone marrow and spleen cells. Cell Tissue Kinet 1970;3:393-403. DOI PubMed

40. Zhang Q, Shi S, Liu Y, et al. Mesenchymal stem cells derived from human gingiva are capable of immunomodulatory functions and ameliorate inflammation-related tissue destruction in experimental colitis. J Immunol 2009;183:7787-98. DOI PubMed PMC

41. Seo B, Miura M, Gronthos S, et al. Investigation of multipotent postnatal stem cells from human periodontal ligament. Lancet 2004;364:149-55. DOI PubMed

42. Miura M, Gronthos S, Zhao M, et al. SHED: stem cells from human exfoliated deciduous teeth. Proc Natl Acad Sci U S A 2003;100:5807-12. DOI PubMed PMC

43. Gronthos S, Mankani M, Brahim J, Robey PG, Shi S. Postnatal human dental pulp stem cells (DPSCs) in vitro and in vivo. Proc Natl Acad Sci U S A 2000;97:13625-30. DOI PubMed PMC 
44. Kern S, Eichler H, Stoeve J, Klüter H, Bieback K. Comparative analysis of mesenchymal stem cells from bone marrow, umbilical cord blood, or adipose tissue. Stem Cells 2006;24:1294-301. DOI PubMed

45. Zuk PA, Zhu M, Ashjian P, et al. Human adipose tissue is a source of multipotent stem cells. Mol Biol Cell 2002;13:4279-95. DOI PubMed PMC

46. Matsubara T, Suardita K, Ishii M, et al. Alveolar bone marrow as a cell source for regenerative medicine: differences between alveolar and iliac bone marrow stromal cells. J Bone Miner Res 2005;20:399-409. DOI PubMed

47. Morsczeck C, Götz W, Schierholz J, et al. Isolation of precursor cells (PCs) from human dental follicle of wisdom teeth. Matrix Biol 2005;24:155-65. DOI PubMed

48. Sonoyama W, Liu Y, Fang D, et al. Mesenchymal stem cell-mediated functional tooth regeneration in swine. PLoS One 2006;1:e79. DOI PubMed PMC

49. Fisher SA, Cutler A, Doree C, et al. Mesenchymal stromal cells as treatment or prophylaxis for acute or chronic graft-versus-host disease in haematopoietic stem cell transplant (HSCT) recipients with a haematological condition. Cochrane Database Syst Rev 2019;1:CD009768. DOI PubMed PMC

50. Goldberg A, Mitchell K, Soans J, Kim L, Zaidi R. The use of mesenchymal stem cells for cartilage repair and regeneration: a systematic review. J Orthop Surg Res 2017;12:39. DOI PubMed PMC

51. Golpanian S, Wolf A, Hatzistergos KE, Hare JM. Rebuilding the damaged heart: mesenchymal stem cells, cell-based therapy, and engineered heart tissue. Physiol Rev 2016;96:1127-68. DOI PubMed PMC

52. Lalu MM, Sullivan KJ, Mei SH, et al. Evaluating mesenchymal stem cell therapy for sepsis with preclinical meta-analyses prior to initiating a first-in-human trial. Elife 2016;5:e17850. DOI PubMed PMC

53. Dominici M, Le Blanc K, Mueller I, et al. Minimal criteria for defining multipotent mesenchymal stromal cells. The International Society for Cellular Therapy position statement. Cytotherapy 2006;8:315-7. DOI PubMed

54. Monsarrat P, Vergnes JN, Nabet C, et al. Concise review: mesenchymal stromal cells used for periodontal regeneration: a systematic review. Stem Cells Transl Med 2014;3:768-74. DOI PubMed PMC

55. Kamihata H, Matsubara H, Nishiue T, et al. Implantation of bone marrow mononuclear cells into ischemic myocardium enhances collateral perfusion and regional function via side supply of angioblasts, angiogenic ligands, and cytokines. Circulation 2001;104:1046-52. DOI PubMed

56. Liechty KW, MacKenzie TC, Shaaban AF, et al. Human mesenchymal stem cells engraft and demonstrate site-specific differentiation after in utero transplantation in sheep. Nat Med 2000;6:1282-6. DOI PubMed

57. Wen Y, Lan J, Huang H, et al. Application of eGFP to label human periodontal ligament stem cells in periodontal tissue engineering. Arch Oral Biol 2012;57:1241-50. DOI PubMed

58. Yamada Y, Nakamura S, Ito K, et al. Injectable bone tissue engineering using expanded mesenchymal stem cells. Stem Cells 2013;31:572-80. DOI PubMed PMC

59. Wang Y, Chen X, Cao W, Shi Y. Plasticity of mesenchymal stem cells in immunomodulation: pathological and therapeutic implications. Nat Immunol 2014;15:1009-16. DOI PubMed

60. Muhammad SA, Nordin N, Fakurazi S. Regenerative potential of secretome from dental stem cells: a systematic review of preclinical studies. Rev Neurosci 2018;29:321-32. DOI PubMed

61. Nagata M, Iwasaki K, Akazawa K, et al. Conditioned medium from periodontal ligament stem cells enhances periodontal regeneration. Tissue Eng Part A 2017;23:367-77. DOI PubMed PMC

62. Vizoso FJ, Eiro N, Cid S, Schneider J, Perez-Fernandez R. Mesenchymal stem cell secretome: toward cell-free therapeutic strategies in regenerative medicine. Int J Mol Sci 2017;18:1852. DOI PubMed PMC

63. El Moshy S, Radwan IA, Rady D, et al. Dental stem cell-derived secretome/conditioned medium: the future for regenerative therapeutic applications. Stem Cells Int 2020;2020:7593402. DOI PubMed PMC

64. Kwon A, Kim Y, Kim M, et al. Tissue-specific differentiation potency of mesenchymal stromal cells from perinatal tissues. Sci Rep 2016;6:23544. DOI PubMed PMC

65. Ozkul Y, Galderisi U. The impact of epigenetics on mesenchymal stem cell biology. J Cell Physiol 2016;231:2393-401. DOI PubMed

66. Eisenberg LM, Eisenberg CA. Stem cell plasticity, cell fusion, and transdifferentiation. Birth Defects Res C Embryo Today 2003;69:209-18. DOI PubMed

67. Quesenberry PJ, Abedi M, Aliotta J, et al. Stem cell plasticity: an overview. Blood Cells Mol Dis 2004;32:1-4. DOI PubMed

68. Scuteri A, Miloso M, Foudah D, Orciani M, Cavaletti G, Tredici G. Mesenchymal stem cells neuronal differentiation ability: a real perspective for nervous system repair? Curr Stem Cell Res Ther 2011;6:82-92. DOI PubMed

69. Woodbury D, Schwarz EJ, Prockop DJ, Black IB. Adult rat and human bone marrow stromal cells differentiate into neurons. $J$ Neurosci Res 2000;61:364-70. DOI PubMed

70. Alexanian AR. Epigenetic modulators promote mesenchymal stem cell phenotype switches. Int J Biochem Cell Biol 2015;64:190-4. DOI PubMed

71. Hernández R, Jiménez-Luna C, Perales-Adán J, Perazzoli G, Melguizo C, Prados J. Differentiation of human mesenchymal stem cells towards neuronal lineage: clinical trials in nervous system disorders. Biomol Ther (Seoul) 2020;28:34-44. DOI PubMed PMC

72. Leyendecker A Jr, Pinheiro CCG, Amano MT, Bueno DF. The use of human mesenchymal stem cells as therapeutic agents for the in vivo treatment of immune-related diseases: a systematic review. Front Immunol 2018;9:2056. DOI PubMed PMC

73. Wada N, Gronthos S, Bartold PM. Immunomodulatory effects of stem cells. Periodontol 2000 2013;63:198-216. DOI PubMed

74. Hernández-Monjaraz B, Santiago-Osorio E, Ledesma-Martínez E, Alcauter-Zavala A, Mendoza-Núñez VM. Retrieval of a 
periodontally compromised tooth by allogeneic grafting of mesenchymal stem cells from dental pulp: a case report. J Int Med Res 2018;46:2983-93. DOI PubMed PMC

75. Venkataiah VS, Handa K, Njuguna MM, et al. Periodontal regeneration by allogeneic transplantation of adipose tissue derived multilineage progenitor stem cells in vivo. Sci Rep 2019;9:921. DOI PubMed PMC

76. Shanbhag S, Suliman S, Pandis N, Stavropoulos A, Sanz M, Mustafa K. Cell therapy for orofacial bone regeneration: a systematic review and meta-analysis. J Clin Periodontol 2019;46 Suppl 21:162-82. DOI PubMed

77. Bianchi A, Felice P, Lizio G, Marchetti C. Alveolar distraction osteogenesis versus inlay bone grafting in posterior mandibular atrophy: a prospective study. Oral Surg Oral Med Oral Pathol Oral Radiol Endod 2008;105:282-92. DOI PubMed

78. Dahlin C, Johansson A. Iliac crest autogenous bone graft versus alloplastic graft and guided bone regeneration in the reconstruction of atrophic maxillae: a 5-year retrospective study on cost-effectiveness and clinical outcome. Clin Implant Dent Relat Res 2011;13:305-10. DOI PubMed

79. Nuñez J, Vignoletti F, Caffesse RG, Sanz M. Cellular therapy in periodontal regeneration. Periodontol 2000 2019;79:107-16. DOI PubMed

80. Akbay A, Baran C, Günhan O, Ozmeriç N, Baloş K. Periodontal regenerative potential of autogenous periodontal ligament grafts in Class II furcation defects. J Periodontol 2005;76:595-604. DOI PubMed

81. Chen M, Xu Y, Zhang T, et al. Mesenchymal stem cell sheets: a new cell-based strategy for bone repair and regeneration. Biotechnol Lett 2019;41:305-18. DOI PubMed

82. Dhote R, Charde P, Bhongade M, Rao J. Stem cells cultured on beta tricalcium phosphate (beta-TCP) in combination with recombinant human platelet-derived growth factor - BB (rh-PDGF-BB) for the treatment of human infrabony defects. J Stem Cells 2015;10:243-54. DOI PubMed

83. Ferrarotti F, Romano F, Gamba MN, et al. Human intrabony defect regeneration with micrografts containing dental pulp stem cells: a randomized controlled clinical trial. J Clin Periodontol 2018;45:841-50. DOI PubMed

84. Sánchez N, Fierravanti L, Núñez J, et al. Periodontal regeneration using a xenogeneic bone substitute seeded with autologous periodontal ligament-derived mesenchymal stem cells: a 12-month quasi-randomized controlled pilot clinical trial. J Clin Periodontol 2020;47:1391-402. DOI PubMed

85. Novello S, Debouche A, Philippe M, Naudet F, Jeanne S. Clinical application of mesenchymal stem cells in periodontal regeneration: a systematic review and meta-analysis. J Periodontal Res 2020;55:1-12. DOI PubMed

86. Bright R, Hynes K, Gronthos S, Bartold PM. Periodontal ligament-derived cells for periodontal regeneration in animal models: a systematic review. J Periodontal Res 2015;50:160-72. DOI PubMed

87. Tassi SA, Sergio NZ, Misawa MYO, Villar CC. Efficacy of stem cells on periodontal regeneration: systematic review of pre-clinical studies. J Periodontal Res 2017;52:793-812. DOI PubMed

88. Morsczeck C, Moehl C, Götz W, et al. In vitro differentiation of human dental follicle cells with dexamethasone and insulin. Cell Biol Int 2005;29:567-75. DOI PubMed

89. Nuñez J, Sanz-Blasco S, Vignoletti F, et al. Periodontal regeneration following implantation of cementum and periodontal ligamentderived cells. J Periodontal Res 2012;47:33-44. DOI PubMed

90. Tsumanuma Y, Iwata T, Washio K, et al. Comparison of different tissue-derived stem cell sheets for periodontal regeneration in a canine 1-wall defect model. Biomaterials 2011;32:5819-25. DOI PubMed

91. Iwasaki K, Komaki M, Yokoyama N, et al. Periodontal regeneration using periodontal ligament stem cell-transferred amnion. Tissue Eng Part A 2014;20:693-704. DOI PubMed PMC

92. Liu Y, Zheng Y, Ding G, et al. Periodontal ligament stem cell-mediated treatment for periodontitis in miniature swine. Stem Cells 2008;26:1065-73. DOI PubMed PMC

93. Gonçalves AI, Rodrigues MT, Gomes ME. Tissue-engineered magnetic cell sheet patches for advanced strategies in tendon regeneration. Acta Biomater 2017;63:110-22. DOI PubMed

94. Guo S, Kang J, Ji B, et al. Periodontal-derived mesenchymal cell sheets promote periodontal regeneration in inflammatory microenvironment. Tissue Eng Part A 2017;23:585-96. DOI PubMed

95. Oka M, Miyabe Y, Sugiura N, Nitta K. Cell sheet engineering and kidney diseases. In: Nitta K, editor. Recent advances in the pathogenesis and treatment of kidney diseases. S. Karger AG; 2018. p. 74-80. DOI PubMed

96. Iwata T, Washio K, Yoshida T, et al. Cell sheet engineering and its application for periodontal regeneration. J Tissue Eng Regen Med 2015;9:343-56. DOI PubMed

97. Xie Q, Wang Z, Huang Y, et al. Characterization of human ethmoid sinus mucosa derived mesenchymal stem cells (hESMSCs) and the application of hESMSCs cell sheets in bone regeneration. Biomaterials 2015;66:67-82. DOI PubMed

98. Guo W, He Y, Tang X, et al. Scaffold-free cell pellet transplantations can be applied to periodontal regeneration. Cell Transplant 2014;23:181-94. DOI PubMed

99. Yu M, Ge S, Wang F, et al. The role of systemically delivered bone marrow-derived mesenchymal stem cells in the regeneration of periodontal tissues. Int J Oral Maxillofac Implants 2013;28:e503-11. DOI PubMed

100. Sallum EA, Ribeiro FV, Ruiz KS, Sallum AW. Experimental and clinical studies on regenerative periodontal therapy. Periodontol 2000 2019;79:22-55. DOI PubMed

101. Kantarci A, Hasturk H, Van Dyke TE. Animal models for periodontal regeneration and peri-implant responses. Periodontol 2000 2015;68:66-82. DOI PubMed PMC

102. Sculean A, Chapple IL, Giannobile WV. Wound models for periodontal and bone regeneration: the role of biologic research. Periodontol 2000 2015;68:7-20. DOI PubMed PMC 
103. Singal AG, Higgins PD, Waljee AK. A primer on effectiveness and efficacy trials. Clin Transl Gastroenterol 2014;5:e45. DOI PubMed PMC

104. Lang H, Schüler N, Nolden R. Attachment formation following replantation of cultured cells into periodontal defects--a study in minipigs. J Dent Res 1998;77:393-405. DOI PubMed

105. Paknejad M, Eslaminejad MB, Ghaedi B, et al. Isolation and assessment of mesenchymal stem cells derived from bone marrow: histologic and histomorphometric study in a canine periodontal defect. J Oral Implantol 2015;41:284-91. DOI PubMed

106. Tobita M, Uysal CA, Guo X, Hyakusoku H, Mizuno H. Periodontal tissue regeneration by combined implantation of adipose tissuederived stem cells and platelet-rich plasma in a canine model. Cytotherapy 2013;15:1517-26. DOI PubMed

107. Fu X, Jin L, Ma P, Fan Z, Wang S. Allogeneic stem cells from deciduous teeth in treatment for periodontitis in miniature swine. $J$ Periodontol 2014;85:845-51. DOI PubMed

108. Fawzy El-Sayed KM, Mekhemar MK, Beck-Broichsitter BE, et al. Periodontal regeneration employing gingival margin-derived stem/progenitor cells in conjunction with IL-1ra-hydrogel synthetic extracellular matrix. J Clin Periodontol 2015;42:448-57. DOI PubMed

109. Hu J, Cao Y, Xie Y, et al. Periodontal regeneration in swine after cell injection and cell sheet transplantation of human dental pulp stem cells following good manufacturing practice. Stem Cell Res Ther 2016;7:130. DOI PubMed PMC

110. Li G, Han N, Yang H, et al. SFRP2 promotes stem cells from apical papilla-mediated periodontal tissue regeneration in miniature pig. J Oral Rehabil 2020;47 Suppl 1:12-8. DOI PubMed

111. Nuñez J, Sanchez N, Vignoletti F, et al. Cell therapy with allogenic canine periodontal ligament-derived cells in periodontal regeneration of critical size defects. J Clin Periodontol 2018;45:453-61. DOI PubMed

112. Basan T, Welly D, Kriebel K, et al. Enhanced periodontal regeneration using collagen, stem cells or growth factors. Front Biosci (Schol Ed) 2017;9:180-93. DOI PubMed

113. Li Y, Nan X, Zhong TY, Li T, Li A. Treatment of periodontal bone defects with stem cells from inflammatory dental pulp tissues in miniature swine. Tissue Eng Regen Med 2019;16:191-200. DOI PubMed PMC

114. Liu Z, Yin X, Ye Q, et al. Periodontal regeneration with stem cells-seeded collagen-hydroxyapatite scaffold. J Biomater Appl 2016;31:121-31. DOI PubMed

115. Rezaei M, Jamshidi S, Saffarpour A, et al. Transplantation of bone marrow-derived mesenchymal stem cells, platelet-rich plasma, and fibrin glue for periodontal regeneration. Int J Periodontics Restorative Dent 2019;39:e32-45. DOI PubMed

116. Takewaki M, Kajiya M, Takeda K, et al. MSC/ECM cellular complexes induce periodontal tissue regeneration. J Dent Res 2017;96:984-91. DOI PubMed

117. Baba S, Yamada Y, Komuro A, et al. Phase I/II Trial of autologous bone marrow stem cell transplantation with a three-dimensional woven-fabric scaffold for periodontitis. Stem Cells Int 2016;2016:6205910. DOI PubMed PMC

118. Iwata T, Yamato M, Washio K, et al. Periodontal regeneration with autologous periodontal ligament-derived cell sheets - a safety and efficacy study in ten patients. Regen Ther 2018;9:38-44. DOI PubMed PMC

119. Li Y, Zhao S, Nan X, et al. Repair of human periodontal bone defects by autologous grafting stem cells derived from inflammatory dental pulp tissues. Stem Cell Res Ther 2016;7:141. DOI PubMed PMC

120. Yamada Y, Ueda M, Hibi H, Baba S. A novel approach to periodontal tissue regeneration with mesenchymal stem cells and plateletrich plasma using tissue engineering technology: a clinical case report. Int J Periodontics Restorative Dent 2006;26:363-9. PubMed

121. d'Aquino R, De Rosa A, Lanza V, et al. Human mandible bone defect repair by the grafting of dental pulp stem/progenitor cells and collagen sponge biocomplexes. Eur Cell Mater 2009;18:75-83. DOI PubMed

122. K1 V, Ryana H, Dalvi PJ. Autologous periodontal stem cell assistance in periodontal regeneration technique (SAI-PRT) in the treatment of periodontal intrabony defects: a case report with one-year follow-up. J Dent Res Dent Clin Dent Prospects 2017;11:1236. DOI PubMed PMC

123. Shalini HS, Vandana KL. Direct application of autologous periodontal ligament stem cell niche in treatment of periodontal osseous defects: a randomized controlled trial. J Indian Soc Periodontol 2018;22:503-12. DOI PubMed PMC

124. Rubins R, Tolmie P, Corsig K, Kerr E, Kim D. Subepithelial connective tissue graft with purified rhPDGF-BB for the treatment of mandibular recession defects: a consecutive case series. Int J Periodontics Restorative Dent 2014;34:315-21. DOI PubMed

125. Aimetti M, Ferrarotti F, Gamba MN, Giraudi M, Romano F. Regenerative treatment of periodontal intrabony defects using autologous dental pulp stem cells: a 1-year follow-up case series. Int J Periodontics Restorative Dent 2018;38:51-8. DOI PubMed

126. Aimetti M, Ferrarotti F, Mariani GM, Cricenti L, Romano F. Use of dental pulp stem cells/collagen sponge biocomplex in the treatment of non-contained intrabony defects: a case series. Clin Adv Periodontics 2015;5:104-9. DOI PubMed

127. Fraser JK, Hicok KC, Shanahan R, Zhu M, Miller S, Arm DM. The Celution ${ }^{\circledR}$ system: automated processing of adipose-derived regenerative cells in a functionally closed system. Adv Wound Care (New Rochelle) 2014;3:38-45. DOI PubMed PMC

128. Jäger M, Herten M, Fochtmann U, et al. Bridging the gap: bone marrow aspiration concentrate reduces autologous bone grafting in osseous defects. J Orthop Res 2011;29:173-80. DOI PubMed

129. Nagata MJ, de Campos N, Messora MR, et al. Platelet-rich plasma derived from bone marrow aspirate promotes new cementum formation. J Periodontol 2014;85:1702-11. DOI PubMed 